\title{
Psychological First Aid and Practice Principles in the Coronavirus (COVID-19) Outbreak Process
}

\section{Koronavirüs (COVID-19) Salgın Sürecinde Psikolojik ilk Yardım ve Uygulama ilkeleri}

\author{
(iD Nurhayat KILIÇ BAYAGELDİ
}

Artvin Çoruh University Faculty of Health Sciences, Department of Psychiatric Nursing, Artvin, Turkey

\begin{abstract}
The coronavirus (COVID-19) epidemic, which has recently become common in the world, caused many people to die. The World Health Organization has declared COVID-19 as a pandemic. Pandemic situations disrupt community life by creating collective stress in society. It is known that after the pandemics, there is an increase in the symptoms of anxiety, depression, stress and posttraumatic stress disorder, and the symptoms gain resistance and turn into permanent mental disorders. Psychosocial interventions are recommended using internet technology to prevent the negative consequences of pandemics from turning into permanent mental disorders. At this point, psychological first aid (PFA) is the first and emergency psychosocial support intervention. PFA helps individuals to recover by activating their own coping skills with empathic and pragmatic approaches. PFA can be given using internet technology as physical distance is mandatory during virus outbreaks. In this review study, the principles and practices of PFA that can be applied in the case of COVID-19 epidemic, which has been seen all over the world recently and caused the death of many people. This review article is thought to guide aid providers in epidemic situations and contribute to the development of aid skills.
\end{abstract}

Keywords: Coronavirus, psychological first aid, psychosocial interventions

\section{ÖZ}

Son zamanlarda dünyada yaygın görülmeye başlayan koronavirüs (COVID-19) salgını çok sayıda insanın yaşamını yitirmesine neden olmuştur. Dünya Sağlık Örgütü COVID-19 enfeksiyonunu pandemi olarak ilan etmiştir. Pandemiler, toplumda kolektif stres yaratarak toplum yaşamını sekteye uğratabilmektedir. Yaşanan pandemiler sonrasinda toplumda anksiyete, depresyon ve travma sonrası stres bozukluğu belirtilerinde artışlar olduğu ve belirtilerin direnç kazanarak kalııı ruhsal bozukluklara dönüştüğü bilinmektedir. Pandemilerin olumsuz sonuçlarının kalıcı ruhsal bozukluklara dönüşmesinin engellenmesi için internet teknolojisini kullanarak psikososyal müdahalelerin yapılması önerilmektedir. $\mathrm{Bu}$ noktada ilk ve acil psikososyal destek müdahalesi psikolojik ilk yardımdır (PIY). Psikolojik ilk yardım empatik ve pragmatik yaklaşımlar ile bireylerin kendi baş etme yeteneklerini harekete geçirerek iyileşmelerine yardımcı olur. Psikolojik ilk yardım virüs salgınları sırasında fiziksel mesafe zorunlu olduğu için internet teknolojisi kullanılarak verilebilmektedir. Bu derleme çalışmasında son günlerde tüm dünyada görülen ve çok sayıda insanın ölümüne neden olan COVID-19 salgını durumunda uygulanabilecek psikolojik ilk yardım ilke ve uygulamaları açıklanmaktadır. Bu derleme yazısının, salgın durumlarında yardım sağlayıcılarına rehberlik edeceği ve yardım becerilerinin gelişimine katkı sağlayabileceği düşünülmektedir.

Anahtar Sözcükler: Koronavirüs, psikolojik ilk yardım, psikososyal müdahaleler
Address for Correspondence: Nurhayat KILIÇ BAYAGELDi, Artvin Çoruh University Faculty of Health Sciences, Department of Psychiatric Nursing, Artvin, Turkey

E-mail: nurhayatkilic@yahoo.com ORCID ID: orcid.org/0000-0002-2790-5227
Received: 20.04 .2020

Accepted: 30.09 .2020

Cite this article as: Kılıç Bayageldi N. Psychological First Aid and Practice Principles in the Coronavirus (COVID-19) Outbreak Process. Bezmialem Science 2021;9(2):244-9. 


\section{Introduction}

In every period of history, there were many epidemic diseases that caused societies to be at risk of mass death. The coronavirus pandemic, which has recently started to be seen in Wuhan, China and spread rapidly to many countries, has caused a large number of people to die. At this point, World Health organization (WHO) has declared coronavirus disease-19 (COVID-19) as a pandemic (1-3). It is known that pandemics have psychosocial effects on the individual, society and at the international level $(4,5)$. Studies have reported that after the restriction measures in the pandemic and pandemic process, there are increases in the symptoms of anxiety, depression, anger bursts and post-traumatic stress disorder in the society, and even after the pandemic is over, the symptoms gain resistance and turn into permanent mental disorders (4-12). It is known that psychological interventions are recommended and performed using telephone and web-based online applications and internet technology in order to cope with the psychological problems experienced by individuals during the pandemic process $(4,7)$. Psychological support interventions can help reduce anxiety in the early stages of the pandemic and can also be useful in dealing with the negative effects of situations such as witnessing death and loss of a loved one in the later stages (13). At this point, experts have stated that the first and immediate psychosocial support intervention is psychological first aid (PFA) after disasters, including major pandemics (14-22). PFA interventions are humanitarian and supportive interventions offered to individuals who are in pain and need support and assistance $(20,22)$. PFA is a type of support that can be provided by individuals who will not harm the affected individuals in safe places where respect and privacy are provided (20-23). PFA can be done by phone or online to reduce the spread of viruses during the COVID-19 pandemic. When it is done face to face by healthcare professionals or other individuals in exceptional conditions, physical distance should be maintained and security should be provided $(24,25)$. The purpose of PFA interventions is to help individuals feel calmer, better cope with their difficulties, improve their ability to manage the situation and make informed decisions by reducing the initial distress experienced in disaster situations. PFA can help normalize anxiety and other feelings that individuals experience. It can also contribute to the development of feelings of security, calmness and hope (20-26).

PFA is not a diagnosis, an integrated mental health treatment, or any of the therapies and psychological interpretations performed by professionals. PFA is an early psychosocial intervention approach applied after disasters. PFA is a supportive and practical aid intervention that helps reduce the distress experienced by individuals after events causing serious crisis. PFA does not evaluate serious mental health problems and long-term recovery difficulties of all individuals affected by the disaster and does not include any treatment element. It focuses on understanding the reactions of individuals who have experienced the disaster and have been affected by it. Therefore, it stimulates the individual's ability to cope with empathic and pragmatic approaches and enables individuals to recover $(22,25,27-30)$.
In recent years, various PFA guidelines and models have been published in many disasters, including the COVID-19 pandemic $(20,22,24,25,31-36)$. At the same time, studies have also been conducted to prove that PFA interventions are beneficial and effective psychosocial support interventions for both affected individuals and PFA providers in many catastrophic events in the COVID-19 pandemic (28-30,35-41). Cheng et al. (35) stated that online psychological support interventions were effective for inpatients in their study which they performed to provide PFA to hospitalized patients during the COVID-19 pandemic. Francis et al. (36) stated that both PFA providers and PFA takers were satisfied with the online service as a result of the PFA support given by phone for 4 weeks during the COVID-19 pandemic process in Malaysia, in line with the principles set by the International Federation of Red Cross and Red Crescent Societies (look, listen, link). They stated that PFA interventions were important during the pandemic period because of their wide applicability with short training (36).

In this review, the PFA implementation principles that could be applied in the case of the COVID-19 pandemic, which has recently spread all over the world and caused the death of many people, were explained in line with the principles set out by WHO and the International Federation of Red Cross and Red Crescent Societies. In this review, online PFA interventions for adults were discussed. It is thought that this review can guide PFA providers in pandemic situations and contribute to the development of assistance skills.

\section{Psychological First Aid in the Coronavirus Pandemic}

PFA is evidence-based interventions that focus on the mental health of individuals and address the psychosocial needs of individuals during the COVID-19 pandemic $(24,26,42)$. PFA interventions can improve individuals' ability to cope with an event by increasing individual resilience after trauma $(24,35)$. For this reason, it is important to apply PFA during the pandemic and to teach individuals methods of coping with stress $(13,43)$.

During the pandemic; quarantined individuals, individuals seeking information and support, healthcare professionals, individuals recovering from COVID-19 or losing their relatives, risky groups who may need special assistance, individuals with mental health or substance abuse problems may wish to receive an online PFA (25). It is important to determine the appropriate communication tools, hours and assistance services for effective online assistance. Tools to be used for communication in PFA interventions should be safe, easy to use and have features that can be repaired in a short time in case of technical problems $(24,25)$.

In online PFA interventions, there are individuals who need support, and PFA providers. For PFA interventions, PFA providers must first be identified and trained before starting assistance service. Working files should be prepared for PFA providers and their work should be followed. PFA providers should be able to evaluate their readiness to provide PFA support during the pandemic (25). In order to be able to help the individuals in need in the best way, the PFA provider must be physically and emotionally well-equipped $(20,22,24)$. 
During the COVID-19 pandemic, interviews within the scope of PFA can be conducted by phone or online in order to prevent the spread of the virus $(24,25)$. During the COVID-19 pandemic, PFA providers may need to work from home due to curfew or restrictions (25). In this case, it is important to choose a quiet room before answering a call in order to harmonize the physical environment and not to be disturbed $(24,25)$. The PFA provider should also ensure that confidentiality and privacy are protected during the call. Since it is known that individuals with mental and physical illnesses can call in 24/7 call centers, especially at night, PFA providers who provide night assistance services may need more training and inspection $(24,25)$. Guidelines should be set for answering calls during the COVID-19 pandemic. If it is necessary to record any statistical information such as age or gender, verbal consent is required from the caller. Contact information about health services and health officials should be determined in detail (25). Official sites where up-to-date and accurate information about the COVID-19 pandemic can be accessed, should be known (24). The procedures regarding when and in which situations individuals with severe mental problems should be referred during the pandemic should be clear (25). Since psychoeducational materials can be sent to the callers when necessary, documents containing up-to-date and accurate information should be prepared. Practices should be prepared for PFA providers to protect their health in the face of difficult calls (24-25). The PFA provider should know the implementing regulations and their roles. It is also important to evaluate the aid service process by holding meetings by team members $(20,22,25)$.

The International Red Cross and Red Crescent Societies (2020) published a guide that could be useful in the COVID-19 pandemic, and the basic principles of PFA were explained in the guide as: look, listen and link (25). In the principle of looking; current situation, individuals seeking support, risks, needs of affected individuals and reactions of individuals are addressed $(20,25)$. In the principle of listening; the principles of starting a conversation, listening to the individual effectively, accepting the feelings experienced by the individual, calming the individual experiencing intense stress, asking questions about the individual's needs and concerns, and determining the appropriate solutions for the individual's problems and needs are discussed $(24,25)$. In the principle of linking; information is given about the principles of accessing the right information, encouraging people to connect with their loved ones and social supports, coping skills, and connecting with the special assistance services needed $(24,25)$. All these principles of action provide guidance to the PFO provider in assessing a disaster situation and providing effective assistance to individuals $(20,23)$. WHO stated that PFA providers should know all the stages while fulfilling 3 basic principles and they should help with a sense of responsibility (20).

\section{The Principle of Looking for Assessment of Needs}

In the COVID-19 pandemic period, the needs of the callers, the situation they are in and the real or perceived risks they experience are evaluated. It is important to plan remote support in this evaluation process. At this point, the PFA provider should know how to ask appropriate questions about the individual's needs and concerns, to listen actively, and to respond appropriately without judging the affected individual and creating a new trauma in the individual (20,22-25). They should have sufficient knowledge about effectively managing difficult calls when necessary. (25).

The PFA support can be provided by visual or audio communication tools. When using visual communication tools, it is necessary to communicate empathically, warmly and respectfully with a tone that makes individuals feel cared (25). During communication, it should be spoken clearly. Simple words should be used, jargon and technical terms should not be used. Be a good listener and make individuals feel listened to by giving feedback $(20,22,24,31)$. Focus should be on what the callers want to tell and their needs should be determined. Individuals should be given the information they need in a realistic way. False promises and false assurances should not be given against unknowns. In the aid process; individuals should not be told about the stories or problems of others, and the personal problems and troubles of the assistant should not be stated $(20,22,24,25,31)$.

Due to the pandemic, individuals may be intensely worried and can call PFA providers for support. In this case, the emotions experienced by the individuals should be accepted and should not be judged. Making individuals feel understood can reduce the negative emotion experienced. PFA providers can support the development of feelings of calmness and security in individuals by using a calm tone of voice. Being calm and showing understanding can help people under stress to feel understood, respected, and cared for $(16,20,22,25,31)$. Questions should be asked openly during the PFA interview. Questions should not be asked consecutively and individuals' answers should not be interpreted. Non-judgmental language should be used during the PFA interview $(24,25)$. If visual contact is used, simple visuals should be preferred for psychoeducational messages $(24,25)$.

\section{The Principles of Listening to be Used when Answering a Call}

The PFA provider should be able to communicate compassionately with individuals and develop positive cooperation (22). The PFA provider should know well when and how to initiate contact with individuals, taking into account the readiness of the individuals. When starting the first contact, the PID provider should introduce herself/himself and indicate her/his position and institution $(22,23,25,44)$. In order to address the caller at the first contact, his/her name may be asked. If the individual does not want to say his or her name, the PFA provider should not be insistent. The issues that the individuals are seeking for help should be determined. The PFA provider should be informed about the duration and subject of the call according to the needs of the individuals (25). During the calls, PFA provider helps individuals identify their problems, determines their urgent needs, determines urgent solutions to relieve the anxiety of individuals, and enables the individual to take action $(22,23$ 25,31).

Since there are uncertainties about the virus, individuals who experience feelings of stress and fear should be explained that 
their reactions are normal. It is known that correct and up-todate information can calm people in case of disasters. At the same time, correct and complete information can improve the feelings of security and control in the individual $(16,22,24,25)$. Therefore, the information they need should be conveyed to individuals in a realistic way and individuals should be directed to the right sources for information (24).

The PFA provider should talk to the individual about the way of management of emotions experienced during the pandemic. Usually, methods of coping with difficult situations can be learned $(24,25)$. When necessary, information can be given about simple solutions about useful and harmful coping methods $(16,22)$. Correct breathing and relaxation exercises may be recommended to reduce anxiety and calm down when callers need help with calming techniques $(22,24,25,31)$. Giving information to the individual about stress reactions and teaching stress management can accelerate the return of the individual to a normal life $(22,26,40)$. If the callers are quarantined or isolated, they can be asked what they are doing to protect their physical and mental health, and if necessary, the following recommendations can be given:

Being socially close while maintaining physical distance: In the process of physical distance and social isolation, it can be beneficial to be in contact with family members, business and social friends through e-mail, telephone and social media applications $(24,25,45)$. Watching the same movies with loved ones, reading the same books, meeting in virtual meetings and having a virtual chat while drinking coffee or tea together can be beneficial (25).

Maintaining daily routines: It is useful to plan a daily routine, try to maintain it and make new planning in the coming days.

Setting goals and being active: Setting goals and achieving them increase the sense of control and competence. Goals should be in accordance with realistic conditions. Making a to-do list during the day and marking what has been done as the day progresses can increase the feeling of satisfaction. Things that the individual enjoys such as books to be read or written, music to listen to, coloring, knitting, learning a new language or skill, and relaxing are beneficial (25).

Scheduling time individually or together: It can be helpful to create a to-do list that can be performed solo and together. Activities such as reading aloud to each other, playing board games, watching TV, listening to radio, and taking care of children can be given as examples.

Adding humor to situations: Since smiling reduces anxiety and frustration, it can be helpful to use humor in situations.

Maintaining hope: Making the individual remember the values they believe in and helping them to own them can be helpful in preserving hope.

Using stress-coping techniques: Relaxation techniques can reduce stress levels and can also be useful for managing pain and emotional turmoil $(22,25)$.
Accepting emotions: In stressful situations, many emotions such as anger, disappointment, anxiety, regret, and self-blame can be experienced. Acceptance of emotions may be beneficial, as experienced emotions are normal responses to an abnormal situation $(24,25)$.

\section{Principles of Linking, Referring and Ending a Call}

In disaster situations, daily functionality of individuals may deteriorate in an advanced degree and individuals may need special assistance (16). If the sleep patterns of the callers are impaired, if their daily functionality is severely impaired due to the problems experienced, if they have lost control over their behavior, if they have thoughts of harming themselves and others, if they have intensive substance abuse, if they have existing chronic diseases, if they are in risky groups, if they are exposed to violence and sexual harassment, they may need special assistance. At this point, the PFA provider should direct individuals to the help services they need and to experienced employees who will provide effective service $(20,22,25)$. While referring, the needs and problems of the individuals should be clearly summarized in line with the interviews made with the individuals $(22,23,27)$. Directing individuals to appropriate help centers in line with their urgent needs can help develop a sense of hope in the individual (44).

Physical distance is important during a virus outbreak. However, social interaction is important in reducing the negative impact of trauma. For this reason, it may be asked how the callers communicate with their family, friends or other individuals in a virtual environment. At this point, individuals who are isolated, in quarantine or staying at home should be helped to contact individuals or groups that provide social support in the shortest way $(24,25)$. Internet applications such as telephone, e-mail, skype and other social media tools can be important in providing communication $(22,25,44)$.

Providing information to the individual about stress reactions and teaching stress-reducing methods accelerate the return of the individual to a normal life $(22,44)$. Therefore, the PFA provider can provide information to the affected individual about stress reactions, post-traumatic psychological reactions, useful and harmful coping methods (22). The information given may be effective on individuals' stress and problem solving skills (44).

While continuing to talk using the connection action principle, individuals may be asked what they know about the virus and how they can find new information. In case of need, the individual can be directed to the right sources with up-to-date information. The caller can be asked about the problem he/ she wants to state during the conversation process. If necessary, information can be given about current contact numbers, e-mail or web pages regarding health and social services to be admitted. During the termination phase, the interview can be summarized briefly and the interview is terminated by offering good wishes to the individual $(24,25)$. 


\section{Looking Angry Callers, Listening to Them, and Linking with Them}

In pandemic, individuals' inability to maintain their daily routine, decrease in social and physical contact with those around them, and a significant deterioration of their life routine may cause an uncomfortable feeling (45). As time passes and authorities impose severe restrictions, there may be an increase in calls from angry callers $(20,45)$. In this case, PFA providers should be sufficient in proper communication with angry individuals (25). During the interview with the intensely angry individual, the PFA provider should not use sedative techniques at the beginning of the conversation. Active listening can be helpful in calls with angry callers. When the caller's speech is completed, it is important to give feedback that the PFA provider listens and understands. It is necessary to empathize and not judge (25). When expressing that what the caller has said is understood, a much softer tone of voice and words should be used, not with the tone and words used by the caller. At the same time, trying to express what the caller is saying in other words may help calm down (25). If the conversation progresses to the linking stage, it may be asked whether the caller has talked to other people who experience this situation, whether there is someone to help on social media, and whether the caller has ability to cope with difficult decisions (25). The topics discussed are briefly summarized in the termination phase and the conversation is concluded gently. In some cases, it may not be possible to end the conversation gracefully. In such a case, the PFA provider may terminate the interview by stating that he/she is sorry for not being able to benefit the individual, and by expressing that he/she will gladly help in future interviews and by thanking (25).

\section{Conclusion}

COVID-19 pandemic can cause traumatic effects in society due to many reasons such as widespread transmission potential, high mortality rate, restriction measures and unusual ways of protection (social distancing, isolation). The need for effective psychosocial interventions is increasing in disaster events that have the potential to cause traumatic effects in society, including the COVID-19 pandemic. At this point, PFA interventions are the first and important step of effective emergency psychosocial intervention. PFA intervention and knowledge are known to be beneficial for both PFA providers and affected individuals. At this point, it is recommended to conduct researches that prove the effectiveness of PFA intervention and knowledge during the COVID-19 pandemic. It is thought that the principles of assistance presented in this study will provide guidance to PFA practitioners during the pandemic.

Peer-review: Externally peer reviewed.

Financial Disclosure: The author declared that this study received no financial support.

\section{References}

1. Rubin GJ, Wessely $S$. The psychological effects of quarantining a city. BMJ 2020;368:313.
2. Li W, Yang Y, Liu ZH, Zhao YJ, Zhang Q, Zhang L, et al. Progression of Mental Health Services during the COVID-19 Outbreak in China. Int J Biol Sci 2020;16:1732-8.

3. Mahase E. China coronavirus: WHO declares international emergency as death toll exceeds 200. BMJ 2020;368:408.

4. Wang C, Pan R, Wan X, Tan Y, Xu L, Ho CS, et al. Immediate Psychological Responses and Associated Factors during the Initial Stage of the 2019 Coronavirus Disease (COVID-19) Epidemic among the General Population in China. Int J Environ Res Public Health 2020;17:1729.

5. Ko CH, Yen CF, Yen JY, Yang MJ. Psychosocial impact among the public of the severe acute respiratory syndrome epidemic in Taiwan. Psychiatry Clin Neurosci 2006;60:397-403.

6. Kang L, Li Y, Hu S, Chen M, Yang C, Yang BX, et al. The mental health of medical workers in Wuhan, China dealing with the 2019 novel coronavirus. Lancet Psychiatry 2020;7:14.

7. Duan L, Zhu G. Psychological interventions for people affected by the COVID-19 epidemic. Lancet Psychiatry 2020;7:300-2.

8. Rubin GJ, Wessely S. The psychological effects of quarantining a city. BMJ 2020;368:313.

9. Cheng SK, Wong CW, Tsang J, Wong KC. Psychological distress and negative appraisals in survivors of severe acute respiratory syndrome (SARS). Psychol Med 2004;34:1187-95.

10. Greenberg N, Wessely S, Wykes T. Potential mental health consequences for workers in the Ebola regions of West Africa--a lesson for all challenging environments. J Ment Health 2015;24:1-3.

11. Cao W, Fang Z, Hou G, Han M, Xu X, Dong J, et al. The psychological impact of the COVID-19 epidemic on college students in China. Psychiatry Res 2020;287:112934.

12. Sun L, Sun Z, Wu L, Zhu Z, Zhang F, Shang Z, et al. Prevalence and Risk Factors of Acute Posttraumatic Stress Symptoms during the COVID-19 Outbreak in Wuhan, China. MedRxiv Preprint 2020;117.

13. Direk Tecirli N, Ucuz G, Özel F. İzolasyon, Karantina, Sosyal Mesafe ve Ruh Sağlığı. Adli Tip Bülteni 2020;25:33-9.

14. Enhanced SECURE STAIRS team COVID-19 guide - psychological first aid for children and young people. NHS England and NHS Improvement coronavirus 2020;1-5.

15. Shultz JM, Forbes D. Psychological First Aid: Rapid proliferation and the search for evidence. Disaster Health 2013;2:3-12.

16. Vernberg EM, Steinberg AM, Jacobs AK, Brymer MJ, Watson PJ, Osofsky J D et al. Innovations in disaster mental health: psychological first aid. Professional Psychology: Research and Practice 2008;39:3818.

17. World Health Organization. mhGAP intervention guide for mental, neurological and substance use disorders in non-specialized health settings. Geneva: WHO Mental Health Gap Action Programme; 2010. s. 107.

18. Sphere Project. Humanitarian Charter and Minimum Standards in Disaster Response. Geneva: The Sphere Project; 2011;1-402.

19. Inter-Agency Standing Committee. IASC Guidelines on Mental Health and Psychosocial Support in Emergency Settings. Geneva. IASC 2007;1-99. 
20. World Health Organization. Psychological first aid: Guide for field workers. Geneva: WHO 2011;1-64.

21. Shannon MER. Early psychosocial intervention after disaster: Psychological first aid. Health Emergency and Disaster Nursing 2015;2:3-6.

22. Brymer M, Layne C, Jacobs A, Pynoos R, Ruzek J, Steinberg A, et al. Psychological First Aid: Field operations guide. 2nd edition. Los Angeles: National Child Traumatic Stress Network and National Center for PTSD 2006. s. 189.

23. Kilic N, Simsek N. Psychological first aid and nursing J Psychiatric Nurs 2018;9:212-8.

24. New Zealand Red Cross Psychological First Aid for COVID-19 in Aotearoa New Zealand. 2020.

25. Psychosocial Centre. International Federation of Red Cross and Red Crescent Societies (IFRC) Remote PFA during a COVID-19 Outbreak. Final guidance note- March 2020;1-22.

26. Minihan E, Gavin B, Kelly BD, McNicholas F. COVID-19, mental health and psychological first aid. Ir J Psychol Med 2020;37:259-63.

27. Ruzek JI, Brymer MJ, Jacobs AK, Layne CM, Vernberg EM, Watson PJ. Psychological First Aid Journal of Mental Health Counseling 2007;29:17-49.

28. Snider L, Chehil S, Walker D. Psychological first aid. In: Mental Health and Psychosocial Support in Disaster Situations in the Caribbean: Core Knowledge for Emergency Preparedness and Response. Washington: PAHO.; 2012. s. 97-107.

29. Schafer A, Snider L, van Ommeren M. Psychological first aid pilot: Haiti emergency response. Intervention 2010;8:245-54.

30. Plummer CA, Cain DS, Fisher RM, Bankston TQ. Practice challenges in using psychological first aid in a group format with children: A pilot study. Brief Treatment and Crisis Intervention 2008;8:313-26.

31. World Health Organization, CBM, World Vision International \& UNICEF. Psychological First aid During Ebola Disease Outbreaks. WHO, Geneva, September 2014;1-84.

32. Everly GS Jr, Lee McCabe O, Semon NL, Thompson CB, Links JM. The development of a model of psychological first aid for non-mental health trained public health personnel: the Johns Hopkins RAPIDPFA. J Public Health Manag Pract 2014;20:24-9.

33. Everly GS Jr, Barnett DJ, Links JM. The Johns Hopkins model of psychological first aid (RAPID-PFA): curriculum development and content validation. Int J Emerg Ment Health 2012;14:95-103.
34. Farchi M, Levy TB, Gershon BB, Hirsch-Gornemann MB, Whiteson A, Gidron Y. The SIX Cs model for immediate cognitive psychological first aid: From helplessness to active efficient coping. International Journal of Emergency Mental Health and Human Resilience 2018;20:395

35. Cheng W, Zhang F, Hua Y, Yang Z, Liu J. Development of a psychological first-aid model in inpatients with COVID-19 in Wuhan, China. Gen Psychiatr 2020;33:100292.

36. Francis B, Juares Rizal A, Ahmad Sabki Z, Sulaiman AH. Remote Psychological First Aid (rPFA) in the time of COVID-19: A preliminary report of the Malaysian experience. Asian J Psychiatr 2020;54:102240.

37. Landoy BVN, Hechanova MRM, Ramos PAP, Kintanar NSM. The application and adaptation of psychological first aid: The Filipino psychologists experience after Typhoon Haiyan. Philippine Journal of Psychology 2015;48:81-104.

38. Ramirez M, Harland K, Frederick M, Shepherd R, Wong M, Cavanaugh JE. Listen protect connect for traumatized schoolchildren: a pilot study of psychological first aid. BMC Psychol 2013;1:26.

39. Hechanova RM, Ramos PAP, Waelde L. Group-based mindfulness informed psychological first aid after Typhoon Haiyan. Disaster Prevention and Management 2015;24:610-8

40. Cho JHY." Disaster Relief and Psychological First Aid."(2015) Loma Linda: Loma Linda University Electronic Theses, Dissertations\&Projects. 189.

41. Cheung YL. Psychological First Aid As A Public Health Disaster Response Preparedness Strategy For Responders İn Critical Incidents And Disasters, Doctor of Philosophy İn Public Health, The Chinese University of Hong Kong, Hong Kong.; 2014:346.

42. Shah K, Kamrai D, Mekala H, Mann B, Desai K, Patel RS. Focus on Mental Health During the Coronavirus (COVID-19) Pandemic: Applying Learnings from the Past Outbreaks. Cureus 2020;12:7405.

43. Johal SS. Psychosocial impacts of quarantine during disease outbreaks and interventions that may help to relieve strain. $\mathrm{N} Z$ Med J 2009;122:47-52.

44. Pekevski J. First responders and psychological first aid. J Emerg Manag 2013;11:39-48.

45. Brooks SK, Webster RK, Smith LE, Woodland L, Wessely S, Greenberg N, et al. The psychological impact of quarantine and how to reduce it: rapid review of the evidence. Lancet 2020;395:912-20. 